\title{
OBITUARY
}

\section{Victor Froilano Bachmann de Mello}

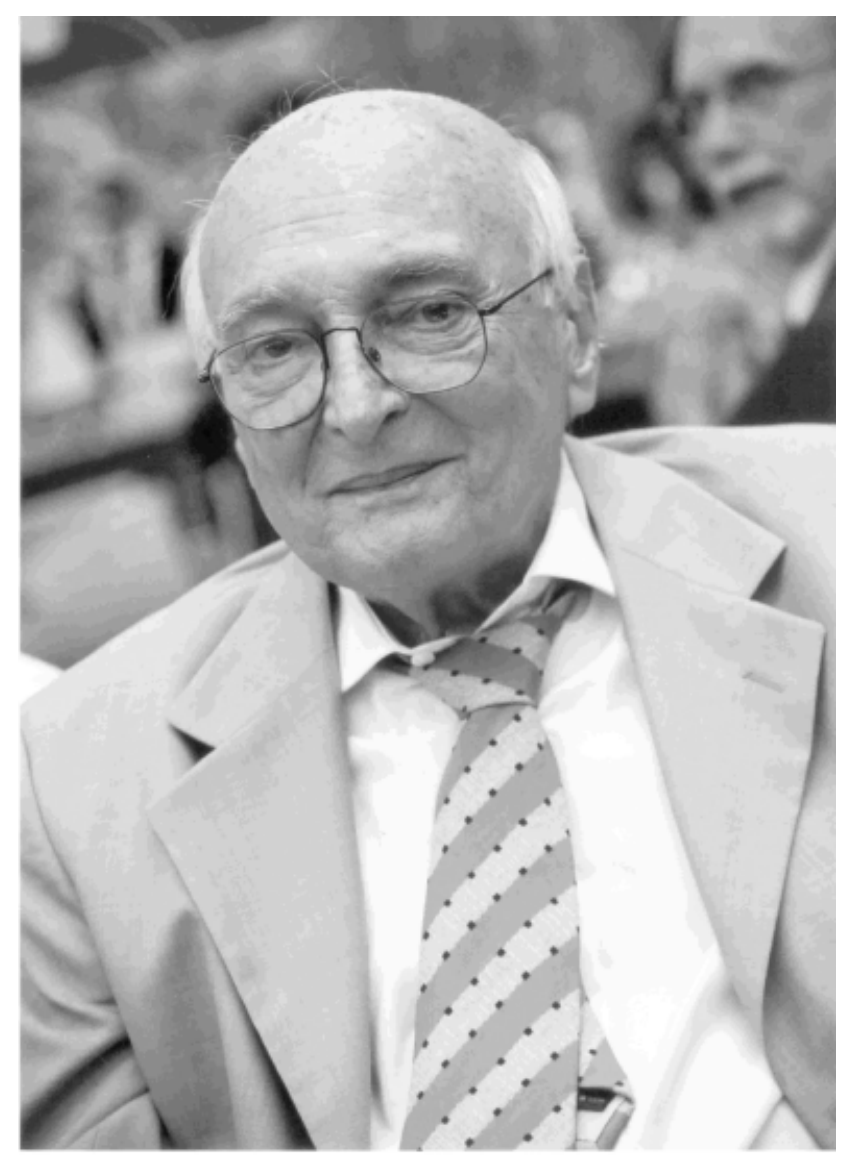

Professor Victor Froilano Bachmann de Mello, 1926-2009

'Water has an unfortunate habit of flowing through every theory.' This used to be the opening assertion of Professor Victor de Mello when he gave the Masters students at MIT his annual course of lectures on the design of earth dams. The remark is typical of Victor de Mello, and one that all can relate to, whether they are geotechnical specialists or ordinary householders! A past president of the International Society of Soil Mechanics and Geotechnical Engineering, Victor was known worldwide, not only as a brilliant geotechnical engineer, but also as a colourful and cultured person who lived life to the full. He loved word play, and aptly described himself as 'specialising in being a practising generalist'.

Victor Froilano Bachmann de Mello was born in Pangim, Goa, on 14 May 1926, and was one of six children. His father was Indo-Portuguese and his mother Swiss German. The early education of the six de Mello children was undertaken at home by their parents. They each learned a musical instrument, in addition to the piano, and were taught painting, European languages and literature. They were also encouraged to take part in sports, including swimming, tennis and horse-riding etc. Victor's parents had planned for their children to be educated in Europe, but the impending Second World War meant that they had to study at British boarding schools in India. At the age of 11 Victor went to Bishop Cotton Boys' School in Bangalore, where he ex- celled, winning many prizes for both academic and sporting achievements.

Victor gained admission to the ETH in Zurich to study civil engineering, but was unable to travel there because of the war. Being Portuguese Goan he was not eligible at that time for entry to any of the top Indian engineering schools. Instead he joined the Interscience Course of Ewing Christian College at Allahabad, and again performed brilliantly in his examinations. In order to complete his third year he had to move once again, this time to Lahore in present-day Pakistan, to the Forman Christian College. Because of his musical ability he used to play the organ in chapel. One day, while he was practising, the Principal stopped him and asked him what profession he intended to follow. Victor explained that he wanted to study civil engineering, but was unable to travel to Zurich. The Principal, Dr C. H. Rice, aware of Victor's first-term grades, responded: 'Why don't you go to MIT? It is an engineering school of the highest ranking.' It turned out that Dr Rice was the brother-in-law of Karl T. Compton, President of MIT. Dr Rice wrote a letter to Compton, and some weeks later a telegram arrived, stating simply: 'Victor de Mello admitted July 1, 1944, Karl T. Compton'.

Once again Victor's academic achievements were outstanding. By accelerating his studies, he obtained his BSc degree in June 1946, and completed his MSc in September 1946. He had planned to move to Brazil, but was persuaded by D. W. Taylor to stay on as his research associate to conduct the new Soil Solidification Research Contract from the US Corps of Engineers. On completion of his doctorate Victor began work on a new research contract on the shear strength of clays. But he wanted the action and creativity of real civil engineering, and its service to society, so after seven months he ended his five-year association with MIT. In particular, the challenges of the brave new world of Brazil beckoned him: there, in August 1949, he joined the hydroelectric power department of the Canadian-Brazilian Light and Power Company, São Paulo. Between 1951 and 1967 he was, successively, Chief Design Engineer, Technical Director and Superintending Director of Geotécnica, Inc., which at the time was by far the largest company for consulting and special services in geotechnical engineering in Latin America.

Victor de Mello set up as a private consultant in 1968, in which capacity he soon became concerned with a significant proportion of the major civil engineering projects in Brazil, involving expenditure of billions of dollars per year on tunnels, railways, industrial and mining projects. He is best known for his expertise in the design of embankment dams (numbering over 200), particularly those constructed from residual soils and saprolites, for which traditional approaches based on the properties of sedimentary soils are not satisfactory. He also advised on the design of many other ground engineering projects worldwide, including open-pit mining, tunnels and underground works, deep excavations, foundations for high-rise buildings and heavy industrial plant, bridges, highways and railways, ports, jetties and breakwaters. He was on the board of consultants for many international projects, including the one that advised on the catastrophic slope failures that took place in Hong Kong in the early 1970 s. 
In addition to his consulting work Victor took on the mantle of teacher and scholar. In 1957 he was appointed Professor of Soil Engineering at Mackenzie University in São Paulo, and in 1967 he became Professor of Soil Engineering at São Paulo University. He had many part-time appointments, the most notable being Senior Visiting Professor at MIT in 1966-1967, and thereafter a frequent guest lecturer. He was also very active in his chosen profession. From 1964 to 1966 he was President of the Brazilian Society of Soil Mechanics (of which he was a founding member), and was the first recipient of its Terzaghi Prize in 1966 and again in 1978. He was Vice President of the International Society of Rock Mechanics for South America (1970-1974) and Vice President of the International Society of Soil Mechanics for South America (1973-1977).

In June 1981 Victor de Mello was elected President of the International Society of Soil Mechanics and Foundation Engineering (now ISSMGE), exactly 35 years to the day since receiving his BSc degree from President Compton of MIT. Characteristically, he threw himself wholeheartedly into the service of the Society. He initiated a root-andbranch revision of the Statutes, and increased local and regional activity by encouraging an expansion in the number and diversity of the technical committees. During his four-year term of office he travelled to over 30 countries to attend conferences and congresses, where he invariably presented papers and gave lectures, never once repeating the topic. Often at his side was his inspiration and encourager-his wife Maria Luiza. Sadly, she died in August 1990.

For an engineer in private practice Victor de Mello was a prolific author. He published over 150 papers and numerous invited state-of-the-art reports on a wide range of subjects, including the application of probability and statistics to engineering design philosophy, which was a particular passion of his. He received many awards, among the most notable being Foreign Associate of the US National Academy of Engineering, the Manuel Rocha Prize from the government of Portugal, and Fellow of the Third World Academy of Sciences - now named TWAS. The latter honour was particularly appropriate, as Victor often ex- pressed concern about the dangers of developing countries becoming over-reliant on the advice of experts imported from the developed world. He would call it the import of technical don't know how!

Victor de Mello was highly articulate; he loved debate, and would go out of his way to seek it. Often his overexuberant questioning would be misunderstood as criticism, but he was always prepared to revise his views in the light of debate. His state-of-the-art reports were meticulously researched and referenced, and he thoroughly disapproved of any work that did not properly recognise previously published findings. He had a refreshing knack of turning perceived wisdom on its head. An example of this was the 17th Rankine Lecture (which he characteristically began with a Roman fable and ended with an Arabic proverb) in which he referred to the current emphasis on the importance of prediction in design, as epitomised by Lambe's 1973 Rankine Lecture. While accepting that prediction is a necessary vehicle for adequate design decisions, Victor pointed out that often 'our ability to predict what will happen is poor compared to our ability to predict what will not happen.' He went on to argue that, wherever possible, good design should aim at avoiding over-reliance on precise predictions. It should aim at developing design solutions that eliminate the uncertainties.

Victor de Mello's love of literature and music, and his enjoyment of outdoor activities, can be traced to his early education at home. He read widely, particularly enjoying Western classics. He loved the rhythms of Portuguese fados, Brazilian popular music and Indian ragas. He enjoyed horse riding, played tennis regularly, and later in life became a proficient windsurfer.

After a long illness Victor de Mello died peacefully at his home in São Paulo on 1 January 2009. He leaves his second wife Maria, his daughter Lucia Beatriz, his son Luiz Guilherme, and four grandchildren. Engineers of all disciplines have much to learn from this brilliant, inspiring and cultured man. Above all we can learn from his insistence that we are human beings first, engineers second, and specialists third the order being very important.

J. Burland 